\title{
Ferritin levels and risk of metabolic syndrome: meta-analysis of observational studies
}

\author{
Victoria Abril-Ulloa ${ }^{1,2}$, Gemma Flores-Mateo ${ }^{3,4}$, Rosa Solà-Alberich ${ }^{1,5}$, Begoña Manuel-y-Keenoy ${ }^{6}$ \\ and Victoria Arija ${ }^{1,3,6,7^{*}}$
}

\begin{abstract}
Background: Elevated ferritin levels have been associated with single cardiovascular risk factors but the relationship to the presence of metabolic syndrome is inconclusive.

The aim of this systematic review and meta-analysis of published observational studies was to estimate the association between serum ferritin levels and metabolic syndrome in adults.

Methods: The Pubmed, SCOPUS and the Cochrane Library databases were searched for epidemiological studies that assessed the association between ferritin levels and metabolic syndrome and were published before September 2013. There were no language restrictions. Two investigators independently selected eligible studies. Measures of association were pooled by using an inverse-variance weighted random-effects model. The heterogeneity among studies was examined using the $R$ index. Publication bias was evaluated using the funnel plot.

Results: Twelve cross-sectional, one case-control and two prospective studies met our inclusion criteria including data from a total of 56,053 participants. The pooled odds ratio (OR) for the metabolic syndrome comparing the highest and lowest category of ferritin levels was 1.73 ( $\left.95 \% \mathrm{Cl}: 1.54,1.95 ; P^{2}=75,4 \%\right)$. Subgroup analyses indicate that pooled OR was 1.92 (95\% Cl: 1.61, 2.30; $\left.P^{2}=78 \%\right)$ for studies adjusting for C-reactive protein (CRP), and 1.52 (95\% Cl:1. 36, 1.69; $\left.P^{2}=41 \%\right)$ for studies that did not adjust for CRP $(P=0.044)$. This finding was remarkably robust in the sensitivity analysis. We did not find publication bias.
\end{abstract}

Conclusions: The meta-analysis suggests that increased ferritin levels are independently and positively associated with the presence of the metabolic syndrome with an odds ratio higher than 1.73.

Keywords: Ferritin, Metabolic syndrome, Meta-analysis

\section{Background}

The metabolic syndrome, currently prevalent in $20 \%-25 \%$ of the world's adult population, is a significant risk factor for cardiovascular disease, type 2 diabetes and cancer [1]. It consists of clinical symptoms and abnormal lab results, including abdominal obesity, insulin resistance, hyperglycemia, hyperlipidemia, and hypertension [1].

Ferritin, an ubiquitous intracellular protein that is key in the regulation of iron homeostasis, is an accepted biomarker to evaluate body iron stores [2]. However,

\footnotetext{
*Correspondence: victoria.arija@urv.cat

${ }^{1}$ Faculty of Medicine and Health Sciences, Universitat Rovira i Virgili, Reus, Spain

${ }^{3}$ Unitat de Suport a la Recerca Tarragona-Reus, Institut Universitari d'Investigació en Atenció Primària Jordi Gol (IDIAP Jordi Gol), Tarragona, Spain

Full list of author information is available at the end of the article
}

increasing evidence indicates that elevated body iron stores may be associated with adverse health outcomes. Elevated serum ferritin levels have been demonstrated to independently predict type 2 diabetes mellitus in several meta-analyses [3-5]. In cross-sectional studies, elevated ferritin levels have been associated with hypertension [6], dyslipidemia $[7,8]$, elevated fasting insulin and blood glucose levels [9], and central adiposity [10]. However, no meta-analysis has specifically focused on high ferritin blood concentrations in relation to the presence of the metabolic syndrome. Moreover, the presence of inflammation has not been systematically taken into account, leading to conflicting results [11-22].

\section{Biomed Central}

C 2014 Abril-Ulloa et al.; licensee BioMed Central Ltd. This is an Open Access article distributed under the terms of the Creative Commons Attribution License (http://creativecommons.org/licenses/by/2.0), which permits unrestricted use, distribution, and reproduction in any medium, provided the original work is properly credited. The Creative Commons Public Domain Dedication waiver (http://creativecommons.org/publicdomain/zero/1.0/) applies to the data made available in this article, unless otherwise stated. 
Evaluating if high serum ferritin is associated with the metabolic syndrome is relevant for both the clinician and the public health areas that focus on screening and prevention.

In order to address this issue we aimed in this study to meta-analyze the findings of published original research articles investigating the relationship between serum ferritin and the presence of the metabolic syndrome in adults of both genders in prospective cohort and crosssectional studies.

\section{Methods}

\section{Search strategy}

We searched PubMed (http://www.ncbi.nlm.nih.gov/ pubmed), the SCOPUS and Cochrane Central Database for observational studies, investigating the association between serum ferritin levels and metabolic syndrome.

We used free text and the Medical Subject Heading (MeSH) terms metabolic syndrome, iron, ferritin, transferrin, ferritins, iron stores, iron status, iron intake, iron consumption, heme iron. The search period was allinclusive until February 2014; no language restrictions were added. We also reviewed the reference lists of the retrieved original articles.

\section{Study selection}

We included all observational studies (cross-sectional, case-control and prospective) that were conducted in adults aged $\geq 18$ years, assessing the association between serum ferritin and metabolic syndrome.

Exclusion criteria were the following: 1) no original research (reviews, editorials, non-research letters); 2) case reports and case series; 3) studies concerning children, adolescents and pregnant women; 4) study subjects with hemochromatosis, chronic liver disease, liver cirrhosis or chronic renal diseases; and 5) studies with Type 1 diabetes mellitus or Type 2 diabetes mellitus participants.

For study populations generating more than one report [20,22-26], we selected the study with the largest number of participants [20,22,27].

\section{Data extraction and quality assessment}

Two investigators (G.F-M and V.A-U) independently reviewed the search results and selected articles to determine eligibility and to extract study data. A third investigator independently reviewed the published data (V.A). They resolved discrepancies by consensus. Extracted data included information on the study design (prospective cohort, cross-sectional and other designs), measures of association used (odds ratio or hazard ratio), country of origin, population, sex, average age of participants, number of participants, ferritin assay technique, ferritin levels, metabolic syndrome criteria and outcomes.
The investigators of the original studies were contacted if relevant information on eligibility or key study data were not available in the published report.

To assess study quality, we used the STROBE statement of observational studies [27]. Each of the criteria was categorized as clearly yes or clearly no. A score between 0 and 22 was assigned to allow for quality analysis (0 denoted noncompliance with any criteria, and 22 denoted fulfillment of all criteria). Our meta-analysis was registered on the website of the International prospective register of systematic reviews, PROSPERO (CRD42012002258).

\section{Data synthesis and statistical analysis}

Measures of association (odds ratio (OR), relative risks or hazard ratios) and their 95\% CIs were extracted or derived by using the data reported in the publications. When several measures of association were reported, we chose the measure obtained from the model of the highest category for ferritin concentration and as second choice, the measure adjusted for most covariates. For studies that categorized ferritin levels, we compared the risk of metabolic syndrome in the highest with the lowest ferritin category. For studies reporting only mean levels of ferritin in case and non-case subjects [12,14], we used linear discriminant function methods [28] to calculate the OR in a comparison of the 75 th to the 25th percentiles of the ferritin distribution in non-case subjects, assuming a normal distribution for ferritin.

To pool OR estimates from individual studies, we used an inverse variance weighted random-effects model. Heterogeneity was quantified with the $I^{2}$ statistic which describes the proportion of total variation in the study estimates that is due to heterogeneity [29]. To explore sources of heterogeneity, we performed subgroup analysis and meta-regression to evaluate whether results were different depending on the study design (prospective (cohort), cross-sectional and other designs, on the measure of association used (odds ratio or hazard ratio), geographic area (Asian, Europe or American), adjusted for C-reactive protein (CRP) (yes or not), quality of the study ( $<30$ points or equal or higher than 30 points of SCORE statement of 34 as maximum points), ferritin technique assay (immunoradiometric assay RIA; immunoturbidimetric assay, TIA; or others) and study size ( $<300$ or equal or higher than 300 participants).

We used sensitivity analyses to assess the relative influence of each study on the pooled estimates by omitting one study at a time. Finally, we assessed publication bias using funnel plots [30].

Our results were expressed as pooled OR.

Statistical analysis was performed using Stata software (version 11.0; Stata Corp, College Station, TX, USA). 


\section{Results}

\section{Study selection}

The search strategy retrieved 243 unique citations in the Pubmed, 644 in the SCOPUS and 0 in the Cochrane Library (Figure 1). Of these citations, 238 and 636 respectively, were excluded after screening on the basis of title and abstract and 7 after full-text review, leaving twelve cross sectional studies [11-20,22,31], one casecontrol study [21] and two prospective cohort studies $[26,32]$ for final inclusion in the meta-analysis. Fourteen articles were in English and one in Korean (Its abstract was in English). The fifteen studies found [11-22,26,31,32] were published between 2004 and February 2014. One study was performed in the United States [11], nine studies in Asia [13,15-18,20,22,26,31]; four in Europe [12,14,21,32] and one in Chile [19]. The number of subjects per study varied between 155 [19] to 13,084 [26] (Table 1).

The STROBE quality score of studies included 7 had 30 points or more while 5 studies had $<30$ points.

The metabolic syndrome was defined according with the criteria by the National Cholesterol Education Program Adult Treatment Panel III criteria (NCEP ATP III) [33] in all studies except one defined by International Diabetes Federation Task Force on Epidemiology and Prevention [26].

\section{Meta-analysis of serum ferritin levels and metabolic syndrome}

Data from a total of 56,035 participants were analyzed. The pooled OR when comparing the highest to the lowest category of ferritin levels and metabolic syndrome was 1.73 (95\% CI: 1.54, 1.95); heterogeneity: $P<0.001$; $I^{2}=75,4 \%$ (Figure 2). The pooled OR for men was 1.69 (95\% CI: $1.29,2.21)$; heterogeneity: $P<0.001 ; I^{2}=87,7 \%$; for women it was 1.65 (95\% CI: 1.41, 1.94); heterogeneity: $P=0.002 ; I^{2}=63.7 \%$ and for studies that included both genders it was 1.87 (95\% CI: 1.56, 2.23); heterogeneity: $P=0.073 ; I^{2}=53.2 \%$.

Meta-regression and subgroup analysis showed that adjusting by CRP and quality of studies significantly influenced the pooled estimates $(P=0.044$ and $P=0.038$ respectively) (Table 2). An stronger association between ferritin levels and metabolic syndrome was detected in studies adjusted by CRP [OR $=1.92$ (95\% CI: 1.61, 2.30; $\left.\left.I^{2}=78 \%\right)\right]$ compared to studies that did not adjust by CRP $\left[\mathrm{OR}=1.52\right.$ (95\% CI: 1.36, 1.69; $\left.I^{2}=41 \%\right)$. Moreover, studies with high quality ( $\geq 30$ points) showed a stronger association between serum ferritin levels and metabolic syndrome compared to studies with mediumpoor quality ( $<30$ points) $(\mathrm{OR}=1.87$ vs $\mathrm{OR}=1.43)$.

Other sources of heterogeneity investigated, such as study design $(P=0.551)$, measure of association $(P=0.520)$, geographic area $(P=0.239)$, ferritin assay technique $(P=0.091)$, study size $(P=0.152)$, did not influence pooled estimates (Table 2 ).

In sensitivity analyses, the exclusion of individual studies did not modify the estimates substantially and the pooled odds ratio ranged from 1.64 to 1.76 .

\section{Discussion}

The present study is the first meta-analysis summarizing the independent positive association between ferritin levels and the metabolic syndrome. The highest category of ferritin levels was independently associated with a 1.73 higher presence of metabolic syndrome when compared to the lowest category. This association was stronger when adjusted for an inflammatory biomarker such as CRP levels. The initial results of the meta-analysis were consistent when tested for sensitivity analyses.

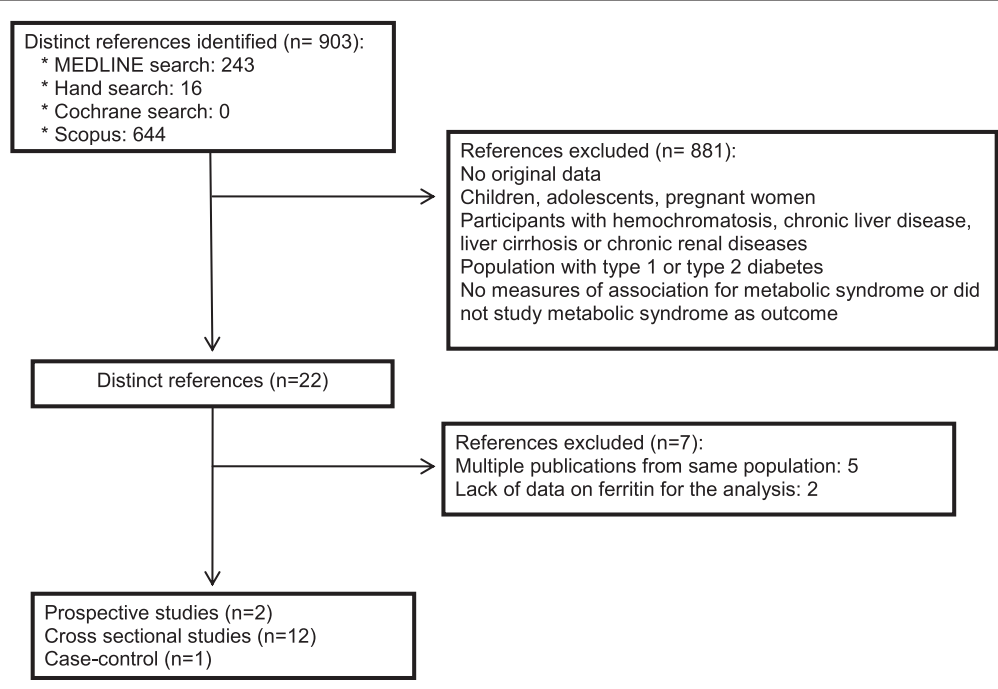

Figure 1 Flow diagram of the study selection process. 
Table 1 Cross sectional and cohort studies on Ferritin level and of the Metabolic Syndrome

\begin{tabular}{|c|c|c|c|c|c|c|c|c|c|c|c|}
\hline \multirow{2}{*}{$\begin{array}{l}\text { First author } \\
\text { Year (Reference } \\
\text { number) }\end{array}$} & \multirow[t]{2}{*}{ Country } & \multirow{2}{*}{$\begin{array}{l}\text { Study } \\
\text { design }\end{array}$} & \multirow[t]{2}{*}{ Population } & \multirow{2}{*}{$\begin{array}{l}\text { Men } \\
(\%)\end{array}$} & \multirow{2}{*}{$\begin{array}{l}\text { Age } \\
\text { years }\end{array}$} & \multirow{2}{*}{ Sample } & \multirow{2}{*}{$\begin{array}{l}\text { Ferritin } \\
\text { assay }\end{array}$} & \multirow{2}{*}{$\begin{array}{l}\text { Metabolic } \\
\text { syndrome } \\
\text { criteria }\end{array}$} & \multicolumn{2}{|c|}{ Ferritin concentration $(\mu \mathrm{g} / \mathrm{l})$} & \multirow{2}{*}{$\begin{array}{l}\text { *Quality } \\
\text { score }\end{array}$} \\
\hline & & & & & & & & & Men & Women & \\
\hline Jehn, 2004 [11] & U.S. & Cross-sectional & $\begin{array}{l}\text { NHANES III (1988-1994) } \\
\text { U.S. Population }\end{array}$ & 48 & 48 & 5,949 & RIA & NCEP ATPIII & Q1:62 ${ }^{\mathrm{a}} \mathrm{Q} 4: 318^{\mathrm{a}}$ & $\begin{array}{l}\text { Premenopausal: Q1:1 1 }{ }^{\mathrm{a}} \mathrm{Q} 4: 89^{\mathrm{a}} \\
\text { Postmenopausal: Q1:35 } \mathrm{Q} 4: 212^{\mathrm{a}}\end{array}$ & 30 \\
\hline Bozzini, 2005 [12] & Italy & Cross-sectional & Verona Heart Project & 73 & 58 & 479 & NIA & NCEP ATPII & \multicolumn{2}{|c|}{$\begin{array}{l}\text { Both genders: With MS: } 124(111-138)^{\mathrm{b}} \\
\text { Without MS: } 83(73-94)^{\mathrm{b}}\end{array}$} & 19 \\
\hline Choi, 2005 [13] & Korea & Cross-sectional & $\begin{array}{l}\text { Welfare Centers of } \\
\text { Seoul Metropolitan }\end{array}$ & 0 & 72 & 959 & EIA & NCEP original & & $\begin{array}{l}\text { With MS: } 74 \pm 2^{c} \\
\text { Without MS: } 59 \pm 2^{c}\end{array}$ & 28 \\
\hline Soto González 2006 [14] & Spain & Cross-sectional & $\begin{array}{l}\text { Patients of the Endocrinoloy } \\
\text { and Nutrition Service of } \\
\text { Hospital }\end{array}$ & 34 & 38 & 598 & RIA & NCEP ATPIII & \multicolumn{2}{|c|}{$\begin{array}{l}\text { Both genders: With MS: } 133.9 \pm 141.1^{d} \\
\text { Without MS: } 66.8 \pm 71.8^{d}\end{array}$} & 31 \\
\hline Vari, 2007 [32] & France & $\begin{array}{l}\text { Prospective } \\
\text { cohort }\end{array}$ & $\begin{array}{l}\text { DESIR cohort French people } \\
6 \text { years of follow up }\end{array}$ & 49 & 47 & 944 & NIA & NCEP ATPIII & At baseline $178 \pm 90^{d}$ & $\begin{array}{l}\text { At baseline Premenopausal } \\
\text { women: } 56 \pm 40^{d} \text { Postmenopausal } \\
\text { women: } 92 \pm 54^{d}\end{array}$ & 32 \\
\hline Shi, 2008 [15] & China & Cross-sectional & $\begin{array}{l}\text { The } 2002 \text { National Nutrition } \\
\text { and Health survey }\end{array}$ & 46 & $40-49$ & 2,816 & RIS & NR & Q4:257 $(176-500)^{e}$ & Q4:170 $(96-504)^{\mathrm{e}}$ & 30 \\
\hline Sun, 2008 [16] & China & Cross-sectional & $\begin{array}{l}\text { Nutrition and Health of } \\
\text { Aging population }\end{array}$ & 44 & 58 & 3,165 & TIA & NCEP ATPIII & $\begin{array}{l}\text { Q1:71 }(68-73.2)^{\mathrm{b}} \\
\text { Q4:327 }(316-340)^{\mathrm{b}}\end{array}$ & $\begin{array}{l}\text { Q1:52 }(51-54)^{\mathrm{b}} \mathrm{Q} 4: 231 \\
(224-239)^{\mathrm{b}}\end{array}$ & 30 \\
\hline Ryu, 2008 [17] & Korea & Cross-sectional & $\begin{array}{l}\text { Korean Rural GENOMIC } \\
\text { Cohort }\end{array}$ & 38 & 58 & 1,444 & N.R & NCEP ATPIII & $\mathrm{Q} 1: 45 \pm 2^{f} \mathrm{Q} 4: 258 \pm 12^{f}$ & $\mathrm{Q} 1: 17 \pm 2^{f} \mathrm{Q} 4: 131 \pm 1^{f}$ & 32 \\
\hline Kim, $2011[18]$ & Korea & Cross-sectional & Healthy volunteers & 53 & 51 & 7,253 & TIA & NCEP ATPIII & $176 \pm 108^{d}$ & $75 \pm 55^{d}$ & 30 \\
\hline Park, 2012 [26] & Korea & $\begin{array}{l}\text { Prospective } \\
\text { cohort }\end{array}$ & $\begin{array}{l}\text { Check-up of men in Health } \\
\text { Promotion Center }\end{array}$ & 100 & 44 & 13,084 & & $\begin{array}{l}\text { International } \\
\text { Diabetes } \\
\text { Federation }\end{array}$ & At baseline $112 \pm 64^{d}$ & ーーーーーーーーーーー & 31 \\
\hline Kang, 2012 [20] & Korea & Cross-sectional & $\begin{array}{l}\text { South Korean general } \\
\text { population KNANHES } \\
\text { IV (2007-2008) }\end{array}$ & 44 & 48 & 7,346 & RIA & NCEP ATPIII & $\begin{array}{l}\mathrm{Q} 1: 46(33,55)^{\mathrm{g}} \mathrm{Q} 4: 194 \\
(167,247)^{\mathrm{g}}\end{array}$ & Q1:13 $[9,17]^{9}$ Q4:90 $(75,114)^{9}$ & 27 \\
\hline Hämäläinen, 2012 [21] & Finland & Case-control & $\begin{array}{l}\text { People invited to heath } \\
\text { check up in } 2004\end{array}$ & 45 & 52 & 766 & EIA & NCEP ATPIII & $\begin{array}{l}\text { With MS: } 216 \pm 165^{d} \\
\text { Without MS: } 151 \pm 112^{d}\end{array}$ & $\begin{array}{l}\text { With MS: } 94 \pm 75^{\mathrm{d}} \\
\text { Without MS: } 61 \pm 48^{\mathrm{d}}\end{array}$ & 28 \\
\hline Leiva, 2013 [19] & Chile & Cross-sectional & $\begin{array}{l}\text { Research program of Risk } \\
\text { Factors for Cardiovascular } \\
\text { Disease of Talca }\end{array}$ & 31 & 57 & 155 & EIA & NCEP ATPIII & $\begin{array}{l}\text { With MS: } 72(47-112)^{\mathrm{h}} \\
\text { Without MS: } 55(36-96)^{\mathrm{h}}\end{array}$ & $\begin{array}{l}\text { With MS: } 54(34-85)^{\mathrm{h}} \\
\text { Without MS: } 27(13-60)^{\mathrm{h}}\end{array}$ & 30 \\
\hline Chang, 2013 [22] & Taiwan & Cross-sectional & $\begin{array}{l}\text { Third national nutritional } \\
\text { and health survey in Taiwan } \\
\text { (NAHSIT 2005-2008) }\end{array}$ & 43 & 55 & 2,654 & EIA & $\begin{array}{l}\text { NCEP ATPIII } \\
\text { modified }\end{array}$ & $229 \pm 349^{d}$ & $119 \pm 180^{d}$ & 27 \\
\hline Li, 2013 [31] & China & Cross-sectional & $\begin{array}{l}\text { China Health and Nutrition } \\
\text { Survey }\end{array}$ & 47 & 51 & 8,441 & RIA & $\begin{array}{l}\text { NCEP ATPIII } \\
\text { modified }\end{array}$ & Q1:52 $\mathrm{Q} 4: 423^{\mathrm{a}}$ & Q1:12.9 Q4:142.7 & 30 \\
\hline
\end{tabular}

EIA, Electrochemiluminescence immunoassay; NIA, Nephelometric immunoassay; NR, not reported; RIA, immunoradiometric assay; TIA, immunoturbidimetric assay. ${ }^{*}$ Quality score of STROBE Statement.

${ }^{a}$ Median of quartile; ${ }^{b}$ Geometric mean $(95 \% \mathrm{Cl}) ;{ }^{\mathrm{c}}$ Geometric mean $\pm \mathrm{SD} ;{ }^{\mathrm{d}}$ Mean $\pm \mathrm{SD} ;{ }^{\mathrm{e}}$ Mean of quartile (minimum-maximum); ${ }^{\mathrm{f} G e o m e t r i c ~ m e a n ~} \pm \mathrm{SE} ;{ }^{9}$ Median (range); ${ }^{\mathrm{h}} \mathrm{Geometric}$ mean (range).

SD: standard deviation; SE: standard error; Cl: confidence interval; MS: metabolic syndrome; Q1: quartile 1; Q4: quartile 4: T1: tertile 1; T3: tertile 3 . 


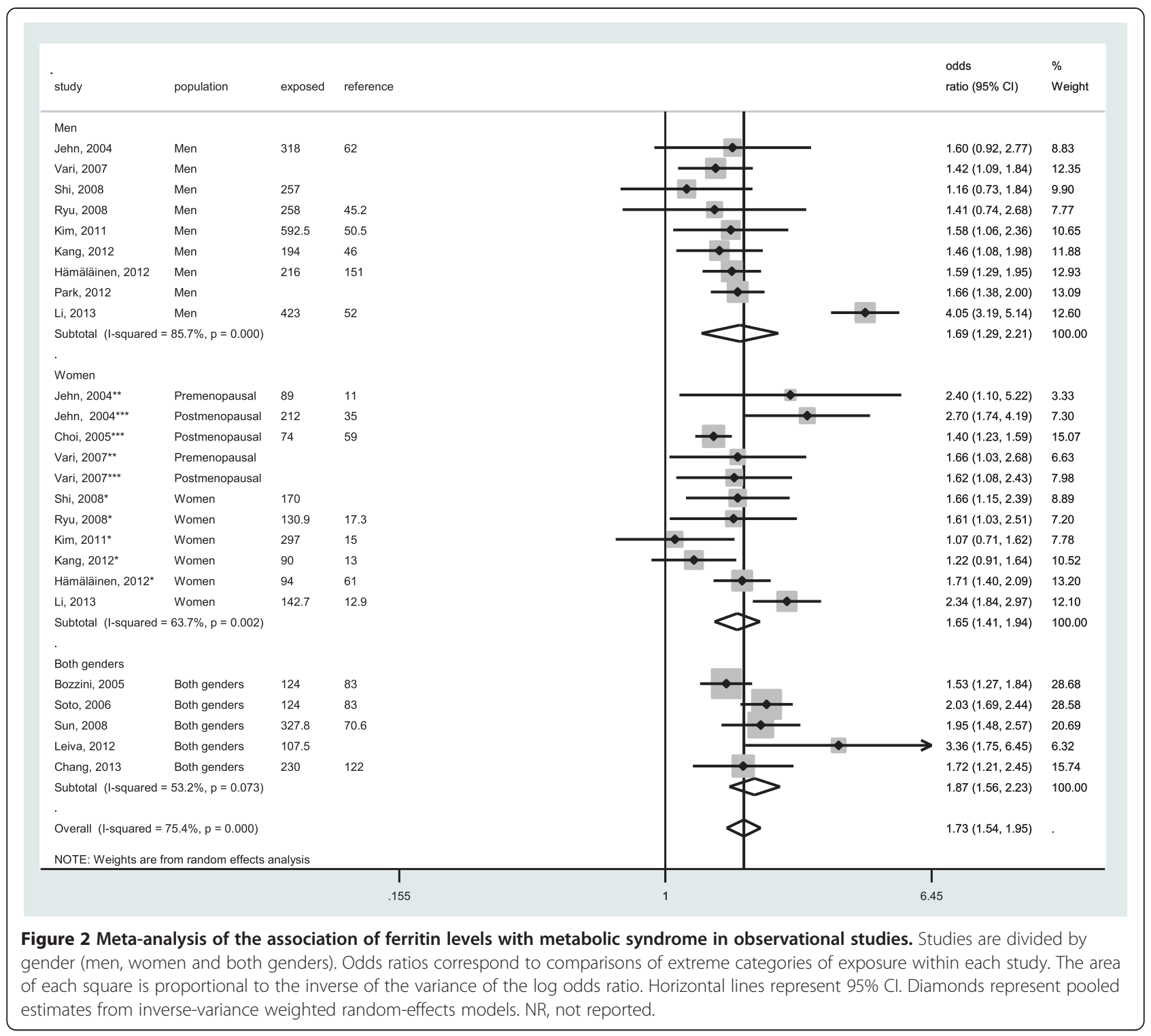

The positive independent association between serum ferritin levels and presence of metabolic syndrome is biologically plausible. Iron is an essential trace element for the human body, involved in cellular processes and a key component of various enzymes. It can also be toxic due to oxidative stress generation by the Fenton reaction, causing organic biomolecular oxidation [34]. This process is at the basis of pathologies like diabetes mellitus, neoplasia and degenerative brain disorders $[34,35]$.

Moreover, the use of iron chelation therapy to reduce serum ferritin levels was associated with improved serum glucose or HDL levels [36]. Houschyar et al. studied the effects of phlebotomy and the control of body iron in patients with metabolic syndrome in a randomized, controlled, single-blind clinical trial. The authors concluded that in patients with metabolic syndrome, phlebotomy with a moderate reduction of body iron stores lowered blood pressure and resulted in improvements of markers of cardiovascular risk and glycemic control [37].

The strengths of our study are that the analysis included a large number of subjects (56,053 participants) and thirteen $[11-22,31,32]$ out of the fifteen studies used the NCEP ATP III criteria to diagnose the metabolic syndrome, which is important to reduce possible bias in the results of the individual studies.

Although the odds ratio may overestimate the risk if interpreted as a relative risk, substantial differences between the odds ratio and the relative risk are seen only when the effect size are large and the initial risk is high [38]. In our study, the meta-regression and subgroup analysis did not show difference between odds ratio and 
Table 2 Stratified odds ratio for metabolic syndrome

\begin{tabular}{|c|c|c|c|c|}
\hline Subgroup & Number of studies & Odds ratio $(95 \% \mathrm{Cl})$ & $I^{2}$ & $P$-value \\
\hline \multicolumn{5}{|l|}{ Study design } \\
\hline Prospective cohort & 2 & $1.59(1.38,1.82)$ & $0 \%$ & \\
\hline Cross-sectional & 12 & $1.78(1.51,2.09)$ & $81 \%$ & \\
\hline Case-control study & 1 & $1.65(1.43,1.91)$ & $0 \%$ & 0.551 \\
\hline \multicolumn{5}{|c|}{ Measure of association } \\
\hline Odds Ratio & 13 & $1.62(1.47,1.79)$ & $47 \%$ & \\
\hline Hazard Ratio & 2 & $1.61(1.49,1.75)$ & $37 \%$ & 0.520 \\
\hline \multicolumn{5}{|l|}{ Geographic area } \\
\hline Asian & 9 & $1.67(1.38,2.02)$ & $84 \%$ & \\
\hline Europe & 4 & $1.66(1.50,1.83)$ & $14 \%$ & \\
\hline American & 2 & $2.41(1.77,3.27)$ & $11 \%$ & 0.239 \\
\hline \multicolumn{5}{|l|}{ Adjusted for CRP } \\
\hline Yes & 9 & $1.92(1.61,2.30)$ & $78 \%$ & \\
\hline No & 6 & $1.52(1.36,1.69)$ & $41 \%$ & 0.044 \\
\hline \multicolumn{5}{|c|}{ Quality of SCORE statement } \\
\hline$<30$ points & 4 & $1.43(1.27,1.61)$ & $0 \%$ & \\
\hline$\geq 30$ points & 11 & $1.87(1.62,2.17)$ & $79 \%$ & 0.038 \\
\hline \multicolumn{5}{|l|}{ Ferritin assay } \\
\hline RIA & 5 & $1.93(1.49,2.51)$ & $85 \%$ & \\
\hline TIA & 2 & $1.53(1.08,2.16)$ & $64 \%$ & \\
\hline Others & 6 & $1.56(1.42,1.70)$ & $17 \%$ & 0.091 \\
\hline \multicolumn{5}{|c|}{ Study size, population } \\
\hline$<300$ & 4 & $1.76(1.512,2.06)$ & $57 \%$ & \\
\hline$\geq 300$ & 11 & $1.70(1.46,1.98)$ & $78 \%$ & 0.152 \\
\hline
\end{tabular}

CRP, C-reactive protein; RIA, immunoradiometric assay; TIA, immunoturbidimetric assay.

hazard ratio ( $\mathrm{p}$ meta-regression $=0.520)(1.61$ vs 1.62$)$, for this reason we combined odds ratio and hazards ratio in pooling analysis.

Another limitation of this meta-analysis is related to the high heterogeneity. However, this elevated heterogeneity was not explained by the study design, type of measure of association, geographic area, ferritin assay technique or study size. Only the use or not of the inflammatory biomarker CRP as control variable and the quality of the studies ( $\geq 30$ points or $<30$ points) were identified as sources of heterogeneity by the subgroup analyses and meta-regression. A possible explanation is that serum ferritin level is an acute-phase reactant and, in the presence of acute or chronic inflammation, may raise several-fold above baseline levels $[39,40]$. By adjusting by CRP, a proinflammatory biomarker, we controlled for the confounder effect of inflammation, and thus, the association between ferritin levels, as a marker of excessive body iron stores, and the metabolic syndrome was strengthened. We therefore believe it is advisable to use a biomarker of inflammation in the studies investigating the relationship between ferritin and the metabolic syndrome and to ensure that the studies are of high methodological quality.

Another important limitation of this meta-analysis is that cross sectional studies cannot be used to infer a causal role of serum ferritin on the risk of developing metabolic syndrome. Indeed, the mechanisms underlying the relationship between increased ferritin and the metabolic syndrome still need to be clarified. However, we can consider that the results from the twelve cross sectional studies [11-20,22,31], one case-control study [21] are supported by the results of two prospective studies [26,32], conducted in France (944 participants) and in Korea (13,084 participants) [26,32], which established that high levels of serum ferritin preceded the development of metabolic syndrome.

Supporting the biologically plausible pathogenic role of elevated iron, there are other longitudinal studies that noted that high serum ferritin could be a risk factor to develop chronic diseases, especially those related to the metabolic syndrome. Recently, in a Korean cohort on 
17,812 healthy men, elevated serum ferritin levels were identified as a predictive factor for obesity [41]. Furthermore, the evidence on a relationship between excess iron and cardiovascular disease has steadily increased over the years $[8,42,43]$. Moreover, several prospective studies have identified excess iron as a risk factor for T2DM. In the Nurses' Health Study cohort the subjects in the highest quintile had a 2.5 fold higher diabetes-risk than those in the lowest quintile [40]. Similarly, results from the cohort of the European Prospective Investigation into Cancer and Nutrition study (EPIC) also supported the hypothesis that higher iron stores below the level of haemochromatosis are associated with risk of type 2 diabetes [44]. In addition, two recent systematic review and meta-analysis of published prospective studies have confirmed the same relationship $[3,4]$. Nevertheless, we want to emphasize that our meta-analysis focused on the metabolic syndrome as the primary outcome and that articles on patients with type 2 diabetes mellitus were excluded.

Although several authors have postulated that levels of iron in the upper limit of the normal range are associated with pathological processes $[45,46]$, at present we do not know the cut-off value of serum ferritin concentration that defines the "high level" and that can be considered as a risk factor of metabolic syndrome. The World Health Organization (WHO) has identified levels of ferritin to define iron overload $(>200 \mu \mathrm{g} / \mathrm{L}$ for men and $>150 \mu \mathrm{g} / \mathrm{L}$ for women) [40-47]. In the studies included in our meta-analysis, we observed that cut-offs of ferritin $(\geq 147 \mu \mathrm{g} / \mathrm{L})$ in the highest quartile or quintile $[11,18,20,26]$ and the geometric mean of the highest quartile were similar o even lower to the levels used to define iron overload in men. In women the values of ferritin that were associated with metabolic syndrome were $89 \mu \mathrm{g} / \mathrm{L}$ in premenopausal and $212 \mu \mathrm{g} / \mathrm{L}$ in postmenopausal women [11]. These are lower than the values of iron overload defined by the WHO in premenopausal women $[11,18,20]$.

Some studies have observed that premenopausal women have a lower prevalence of hyperferritinemia compared with postmenopausal women, because of iron losses by menstruation and increased consumption during pregnancy [13].

The results of our meta-analysis suggest that the metabolic syndrome could already develop in men and in premenopausal women at ferritin levels that are lower than the WHO cut-offs for iron overload.

High serum ferritin concentrations could potentially be used as a screening biomarker to detect those at risk of developing the metabolic syndrome and those in the early stages of the disease that can still be reversed by targeted preventive measures. For this purpose, data from other countries and races will also be necessary to strengthen our understanding of this relationship and to establish the correct cut-off values of ferritin for each population group.

\section{Conclusions}

In summary, the results of the present meta-analysis indicate that serum high levels of ferritin are independently and positively associated with the metabolic syndrome. Additional prospective studies are needed to confirm if high serum ferritin is a valid biomarker of metabolic syndrome risk, to evaluate the influence of inflammation and to identify pathological cut-off values.

\section{Abbreviations \\ CRP: C-reactive protein; EIA: Electrochemiluminescence immunoassay; NCEP ATP III: National cholesterol education program adult treatment panel III criteria; NIA: Nephelometric immunoassay; NR: Not reported; OR: Odds ratio; RIA: Immunoradiometric assay; TIA: Immunoturbidimetric assay.}

\section{Competing interests}

The authors declare that they have no competing interests.

\section{Authors' contributions}

$V A-U$ researched data, interpreted, analyzed the data and wrote the manuscript. GF-M researched data, interpreted, analyzed the data and reviewed the manuscript. RS-A contributed to the discussion and reviewed the manuscript. BM-Y-K contributed to the discussion and reviewed the manuscript. VA reviewed the published data before being included in the analysis, interpreted the data, wrote the manuscript, contributed to the discussion, reviewed the manuscript and is the responsible of all data. All authors read and approved the final manuscript.

\section{Acknowledgments}

This work was supported by the Universitat Rovira i Virgili (Spain), the Institut d'Investigació en Atenció Primària (IDIAP) Jordi Gol (Spain), University of Antwerp (Belgium), University of Cuenca (Ecuador) and the grant of SENESCYT (Secretaría Nacional de Educación Superior, Ciencia, Tecnología e Innovación) (Ecuador).

\section{Author details}

${ }^{1}$ Faculty of Medicine and Health Sciences, Universitat Rovira i Virgili, Reus, Spain. ²Dirección de Investigación (DIUC), Universidad de Cuenca, Cuenca, Azuay, Ecuador. ${ }^{3}$ Unitat de Suport a la Recerca Tarragona-Reus, Institut Universitari d'Investigació en Atenció Primària Jordi Gol (IDIAP Jordi Gol), Tarragona, Spain. ${ }^{4} \mathrm{CIBER}$ obn Physiopathology of Obesity and Nutrition, Institute of Health Carlos III (ISCIII), Madrid, Spain. ${ }^{5}$ Institut d'Investigació Sanitària Pere Virgili (IISPV), Reus, Spain. ' University of Antwerp, Antwerp, Belgium. ${ }^{7}$ Nutrition and Public Health Unit, Universitat Rovira i Virgili, C/Sant Llorenç 21, 43201 Reus, Spain.

Received: 14 December 2013 Accepted: 15 April 2014 Published: 21 May 2014

\section{References}

1. Gade W, Schmit J, Collins M, Gade J: Beyond obesity: the diagnosis and pathophysiology of metabolic syndrome. Clin Lab Sci 2010, 23:51-61.

2. Cook JD, Lipschitz DA, Miles LE, Finch CA: Serum ferritin as a measure of iron stores in normal subjects. Am J Clin Nutr 1974, 27:681-687.

3. Bao W, Rong Y, Rong S, Liu L: Dietary iron intake, body iron stores, and the risk of type 2 diabetes: a systematic review and meta-analysis. BMC Med 2012, 10:119.

4. Kunutsor SK, Apekey TA, Walley J, Kain K: Ferritin levels and risk of type 2 diabetes mellitus: an updated systematic review and meta-analysis of prospective evidence. Diabetes Metab Res Rev 2013, 29:308-318.

5. Zhao Z, Li S, Liu G, Yan F, Ma X, Huang Z, Tian H: Body iron stores and heme-iron intake in relation to risk of type 2 diabetes: a systematic review and meta-analysis. PLoS One 2012, 7:e41641. 
6. Piperno A, Trombini P, Gelosa M, Salvioni A, Mariani R, Mancia G: Increased serum ferritin is common in men with essential hypertension. $J$ Hypertens 2002, 20:1513-1518

7. Halle M, Konig D, Berg A, Keul J, Baumstark MW: Relationship of serum ferritin concentrations with metabolic cardiovascular risk factors in men without evidence for coronary artery disease. Atherosclerosis 1997 128:235-240.

8. Williams MJ, Poulton R, Williams S: Relationship of serum ferritin with cardiovascular risk factors and inflammation in young men and women. Atherosclerosis 2002, 165:179-184

9. Mojiminiyi $O A$, Marouf $R$, Abdella NA: Body iron stores in relation to the metabolic syndrome, glycemic control and complications in female patients with type 2 diabetes. Nutr Metab Cardiovasc Dis 2008, 18:559-566.

10. Gillum RF: Association of serum ferritin and indices of body fat distribution and obesity in Mexican American men-the Third National Health and Nutrition Examination Survey. Int J Obes Relat Metab Disord 2001, 25:639-645

11. Jehn M, Clark JM, Guallar E: Serum ferritin and risk of the metabolic syndrome in U.S. adults. Diabetes Care 2004, 27:2422-2428.

12. Bozzini C, Girelli D, Olivieri O, Martinelli N, Bassi A, De Matteis G, Tenuti I, Lotto V, Friso S, Pizzolo F, Corrocher R: Prevalence of body iron excess in the metabolic syndrome. Diabetes Care 2005, 28:2061-2063.

13. Choi KM, Lee KW, Kim HY, Seo JA, Kim SG, Kim NH, Choi DS, Baik SH: Association among serum ferritin, alanine aminotransferase levels, and metabolic syndrome in Korean postmenopausal women. Metabolism 2005, 54:1510-1514

14. Gonzalez AS, Guerrero DB, Soto MB, Diaz SP, Martinez-Olmos M, Vidal O: Metabolic syndrome, insulin resistance and the inflammation markers C-reactive protein and ferritin. Eur J Clin Nutr 2006, 60:802-809.

15. Shi Z, Hu X, Yuan B, Hu G, Pan X, Holmboe-Ottesen G: Coexistence of anaemia and the metabolic syndrome in adults in Jiangsu, China. Asia Pac J Clin Nutr 2008, 17:505-513.

16. Sun L, Franco OH, Hu FB, Cai L, Yu Z, Li H, Ye X, Qi Q, Wang J, Pan A, Liu Y, Lin $X$ : Ferritin concentrations, metabolic syndrome, and type 2 diabetes in middle-aged and elderly chinese. J Clin Endocrinol Metab 2008, 93:4690-4696.

17. Ryu SY, Kim KS, Park J, Kang MG, Han MA: Serum ferritin and risk of the metabolic syndrome in some Korean rural residents. J Prev Med Public Health 2008, 41:115-120.

18. Kim CH, Kim HK, Bae SJ, Park JY, Lee KU: Association of elevated serum ferritin concentration with insulin resistance and impaired glucose metabolism in Korean men and women. Metabolism 2011, 60:414-420.

19. Leiva E, Mujica V, Sepulveda P, Guzman L, Nunez S, Orrego R, Palomo I, Andrews M, Arredondo MA: High levels of iron status and oxidative stress in patients with metabolic syndrome. Biol Trace Elem Res 2013, 151:1-8.

20. Kang HT, Linton JA, Shim JY: Serum ferritin level is associated with the prevalence of metabolic syndrome in Korean adults: the 2007-2008 Korean National Health and Nutrition Examination Survey. Clin Chim Acta 2012, 413:636-641.

21. Hamalainen P, Saltevo J, Kautiainen H, Mantyselka P, Vanhala M: Erythropoietin, ferritin, haptoglobin, hemoglobin and transferrin receptor in metabolic syndrome: a case control study. Cardiovasc Diabetol 2012, 11:116. doi: 10.1186/1475-2840-11-116

22. Chang JS, Lin SM, Huang TC, Chao JC, Chen YC, Pan WH, Bai CH: Serum ferritin and risk of the metabolic syndrome: a population-based study. Asia Pac J Clin Nutr 2013, 22:400-407.

23. Lee BK, Kim Y, Kim Yl: Association of serum ferritin with metabolic syndrome and diabetes mellitus in the South Korean general population according to the Korean National Health and Nutrition Examination Survey 2008. Metabolism 2011, 60:1416-1424.

24. Yoo KD, Ko SH, Park JE, Ahn YB, Yim HW, Lee WC, Park YM, Caces E, Marre M, Grandchamp B, Ducimetière P, DESIR Study Group: High serum ferritin levels are associated with metabolic risk factors in non-obese Korean young adults: Korean National Health and Nutrition Examination Survey (KNHANES) IV. Clin Endocrinol (Oxf) 2012, 77:233-240.

25. Ryoo JH, Kim MG, Lee DW, Shin JY: The relationship between serum ferritin and metabolic syndrome in healthy Korean men. Diabetes Metab Res Rev 2011, 27:597-603.

26. Park SK, Ryoo JH, Kim MG, Shin JY: Association of serum ferritin and the development of metabolic syndrome in middle-aged Korean men: a 5-year follow-up study. Diabetes Care 2012, 35:2521-2526.
27. Von EE, Altman DG, Egger M, Pocock SJ, Gotzsche PC, Vandenbroucke JP: Strengthening the Reporting of Observational Studies in Epidemiology (STROBE) statement: guidelines for reporting observational studies. BM 2007, 335:806-808.

28. Greenland S: Quantitative methods in the review of epidemiologic literature. Epidemiol Rev 1987, 9:1-30.

29. Higgins JP, Thompson SG: Quantifying heterogeneity in a meta-analysis. Stat Med 2002, 21:1539-1558.

30. Egger M, Davey SG, Schneider M, Minder C: Bias in meta-analysis detected by a simple, graphical test. BMJ 1997, 315:629-634.

31. Li J, Wang R, Luo D, Li S, Xiao C: Association between serum ferritin levels and risk of the metabolic syndrome in Chinese adults: a population study. PLoS One 2013, 8:e74168.

32. Vari IS, Balkau B, Kettaneh A, Andre P, Tichet J, Fumeron F: Ferritin and transferrin are associated with metabolic syndrome abnormalities and their change over time in a general population: Data from an Epidemiological Study on the Insulin Resistance Syndrome (DESIR). Diabetes Care 2007, 30:1795-1801

33. Expert Panel on Detection, Evaluation, and Treatment of High Blood Cholesterol in Adults: Executive Summary of The Third Report of The National Cholesterol Education Program (NCEP) Expert Panel on Detection, Evaluation, And Treatment of High Blood Cholesterol In Adults (Adult Treatment Panel III). JAMA 2001, 285:2486-2497.

34. Winterbourn CC: Toxicity of iron and hydrogen peroxide: the Fenton reaction. Toxicol Lett 1995, 82-83:969-974.

35. Sundaram RK, Bhaskar A, Vijayalingam S, Viswanathan M, Mohan R, Shanmugasundaram KR: Antioxidant status and lipid peroxidation in type II diabetes mellitus with and without complications. Clin Sci (Lond) 1996, 90:255-260

36. Cooksey RC, Jones D, Gabrielsen S, Huang J, Simcox JA, Luo B, Soesanto Y, Rienhoff $H$, Abel ED, McClain DA: Dietary iron restriction or iron chelation protects from diabetes and loss of beta-cell function in the obese (ob/ ob lep-/-) mouse. Am J Physiol Endocrinol Metab 2010, 298:E1236-E1243.

37. Houschyar KS, Ludtke R, Dobos GJ, Kalus U, Broecker-Preuss M, Rampp T Brinkhaus B, Michalsen A: Effects of phlebotomy-induced reduction of body iron stores on metabolic syndrome: results from a randomized clinical trial. BMC Med 2012, 10:54 doi: 10.1186/1741-7015-10-54.

38. Davies HT, Crombie IK, Tavakoli M: When can odds ratios mislead? BMJ 1998 316:989-991.

39. Hentze MW, Muckenthaler MU, Galy B, Camaschella C: Two to tango: regulation of Mammalian iron metabolism. Cell 2010, 142:24-38.

40. Jiang R, Manson JE, Meigs JB, Ma J, Rifai N, Hu FB: Body iron stores in relation to risk of type 2 diabetes in apparently healthy women. JAMA 2004, 291:711-717.

41. Park S, Choi W, Oh C, Kim J, Shin H, Ryoo JH: Association between serum ferritin levels and the incidence of obesity in Korean men: a prospective cohort study. Endocr J 2014, 61:215-224.

42. Nassar B, Zayed E, Title LM, O'Neill B, Bata I, Krikland S, Dunn J, Dempsey GI, Tan MH, Johnstone DE: Relation of HFE gene mutations, high iron stores and early onset coronary artery disease. In Can J Cardiol 1998, 14:215-220.

43. Eftekhari M, Mozaffari-Khosravi H, Shidfar F, Zamani A: Relatin between Body Iron Status and Cardiovascular Risk Factors in Patients with Cardiovascular Disease. In Int J Prev Med 2013, 4:911-916.

44. Montonen J, Boeing H, Steffen A, Lehmann R, Fritsche A, Joost HG, Schulze $M B$, Pischon T: Body iron stores and risk of type 2 diabetes: results from the European Prospective Investigation into Cancer and Nutrition (EPIC)-Potsdam study. Diabetologia 2012, 55:2613-2621.

45. Menke A, Fernandez-Real JM, Muntner P, Guallar E: The association of biomarkers of iron status with peripheral arterial disease in US adults. BMC Cardiovasc Disord 2009, 9:34.

46. Yuan XM, Li W: Iron involvement in multiple signaling pathways of atherosclerosis: a revisited hypothesis. Curr Med Chem 2008, 15:2157-72.

47. World Health Organization: Assessing the Iron Status of Populations. In Geneva: WHO; 2007. Available at http://apps.who.int/iris/bitstream/10665/ 75368/1/9789241596107_eng.pdf

\section{doi:10.1186/1471-2458-14-483}

Cite this article as: Abril-Ulloa et al:: Ferritin levels and risk of metabolic syndrome: meta-analysis of observational studies. BMC Public Health 2014 14:483. 